\title{
Is Prenatal Testis Torsion Unsalvageable Event?
}

\author{
Turgay Kacan*, Muhammet Fatih Kilinc and Ali Ayyildiz \\ Department Of Urology, Ankara Training and Research Hospital, Turkey
}

Submission: November 02, 2017; Published: December 21, 2017

*Corresponding author: Turgay Kacan MD, Department of Urology, Ankara Training and Research Hospital, 06230, Ankara Turkey, Tel:+903125953524; Fax:+903123633396; Email: turgaykacan@gmail.com

\section{Abstract}

Etiology of prenatal testicular torsion (PTT) is still unknown and PTT is hard case to diagnose clinically. However, the necessity of surgical management and timing of surgery is also still controversial. Salvage rate of testicles who have immediate surgery is very low in the literature. A case of PTT is pointing out to timing of surgery management plan in testicular torsion is presented.

Abbreviations: PTT: Prenatal testicular torsion; B: Bilateral; R: Right; L: Left; IV: Intravaginal; EV: Extravaginal; h: Hour

\section{Introduction}

Prenatal testicular torsion (PTT) is hard case to diagnose clinically and management plan on the grounds that it is seen rarely [1]. The first hour of birth, enlarged, non tender, firm testicular mass, and discolored scrotum is seen in examination of newborn [2]. The diagnosis of PTT may be difficult due to its rarity. Ultrasonography is beneficial to confirm the diagnosis [3]. After the diagnosis of case, the necessity of surgical operation and timing of surgery is still contradictive $[1,4]$. The aim of this report is pointing out to timing of surgery management plan in testicular torsion.

\section{Case Report}

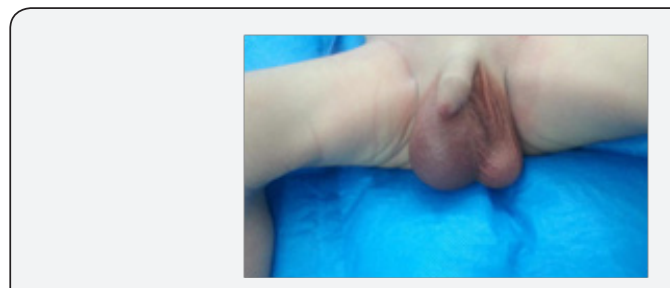

Figure 1: Right testis was enlarged, tender, firm in consistency and the overlying skin was dark red in color.

A 40-week-old male infant of appropriate maturity for gestational age, was born vaginally to a 23-year-old gravida3, para2 woman. The baby's birth weight was $3950 \mathrm{~g}$ with Apgar scores of 8 at 1 minute and 9 at 5 minutes. Since the right hemiscrotum swelling was found at birth, the patient was referred to our department of urology at an hour after birth. Physical examination revealed a normal abdomen, a painless, swollen blue firm right hemi-scrotum that was no transmitted light and a tender right testis (Figure 1). The prenatal ultrasound examinations were normal. Vital signs and laboratory values were normal. Tumor markers were also requested; all resulted normal. An urgent Color Doppler Ultrasonography examination revealed no blood flow in the right testis and blood flow was documented within the left testis. The scrotum was immediately explored. At surgery, the right testis was completely necrotic (Figure 2). The right Orchiectomy was performed. The left orchiopexy was performed due to the risk of asynchronous contralateral testicular torsion. Histhopatological examination of the right testis revealed ischemic necrosis. The postoperative process was uneventful. The left testis was palpable and viable at 3-month follow up.

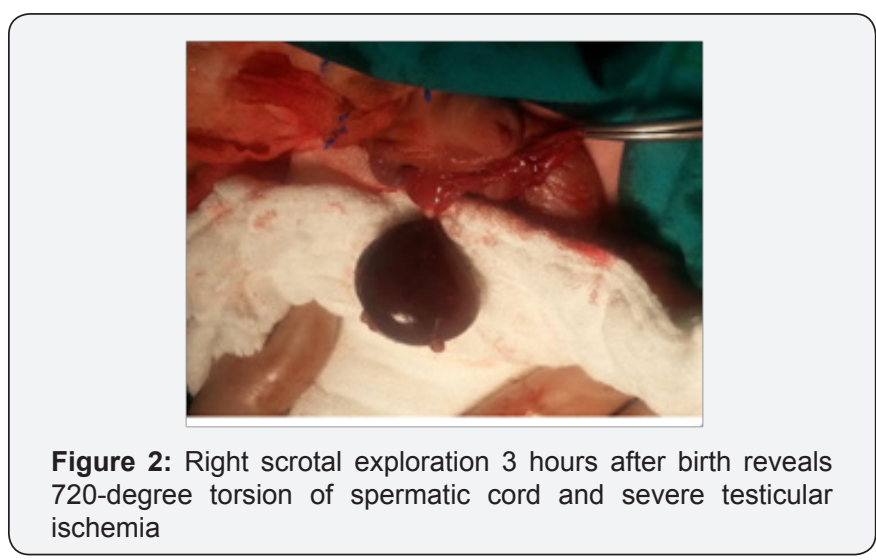

\section{Comment}

Etiology of PTT is still uncertain [1]. High birth weight, difficult birth, breech presentation trauma are factors which go 
along with PTT. Cremasteric contraction, which is occur more than normal inside of the uterus, causing the torsion by increasing mobility layers of tunica vaginalis [1,5]. There is a consideration about torsion, which is diagnosed at the first hours right after the birth, has been occurred period of uterine and it is irreversible $[5,6]$. Animal experiment which has been done; demonstrated that testicular ischemia causes loss of spermatogenesis in the first 6hours and loss of hormonal function in the 12hours [7,8]. The most broad scientific research which is related to the PTT has shown, salvage rate of testicles who have immediate surgery is very low [1,2,4,5,9-13] (Table 1). Furthermore, in these studies atrophia of testicles is unavoidable in follow-up orchiopexy which is done bilateral or unilateral for hormonal functions in bilateral testicular torsion. The case of unilateral prenatal testis torsion we present is different aspect of necessity and timing of surgery. The clinical features demonstrated that sorted testis was infarcts and non-viable. There are variable opinions about risk of anesthesia in the newborns' testicular surgery $[5,14]$. Despite the shortness of surgery and deciding to the operation with family and anesthesiologist, testicle couldn't be salved. This situation was confirmed by histopathology examination. Emergency surgery would not have changed the outcome.

Table 1: Clinical and surgical aspect, surgical timing and salvage rates in patients with prenatal testicular torsion

\begin{tabular}{|c|c|c|c|c|c|c|c|c|}
\hline Study & $\begin{array}{c}\text { Number of } \\
\text { Affected }\end{array}$ & \multicolumn{2}{|c|}{ Side } & Torsion Type & \multicolumn{2}{|c|}{ Time of Surgical Intervention } & \multirow{2}{*}{$\begin{array}{c}\text { Numberof } \\
\text { Testis } \\
\text { Salvaged }\end{array}$} & \multirow{2}{*}{$\begin{array}{c}\text { Rate } \% \\
0\end{array}$} \\
\hline \multirow{3}{*}{$\begin{array}{l}\text { Al-salem et } \\
\text { al.[1] }\end{array}$} & \multirow{3}{*}{12} & B & 1 & \multirow{3}{*}{$\mathrm{EV}$} & $<6 \mathrm{~h}$ & 4 & & \\
\hline & & $\mathrm{R}$ & 4 & & \multirow{2}{*}{$>6 h$} & \multirow{2}{*}{8} & \multirow{2}{*}{$3 / 8$} & \multirow{2}{*}{$37.50 \%$} \\
\hline & & $\mathrm{L}$ & 6 & & & & & \\
\hline \multirow{3}{*}{$\begin{array}{c}\text { Burge et al. } \\
\text { [2] }\end{array}$} & \multirow{3}{*}{18} & B & 1 & $10 \mathrm{EV}$ & \multirow{3}{*}{\multicolumn{2}{|c|}{$>6 \mathrm{~h}$}} & \multirow{3}{*}{$0 / 18$} & \multirow{3}{*}{0} \\
\hline & & $\mathrm{R}$ & $?$ & $3 \mathrm{IV}$ & & & & \\
\hline & & $\mathrm{L}$ & $?$ & 5 other & & & & \\
\hline \multirow{3}{*}{$\begin{array}{l}\text { Yerkes et } \\
\text { al.[4] }\end{array}$} & \multirow{3}{*}{22} & B & 4 & $1 \mathrm{IV}$ & $<6 \mathrm{~h}$ & 2 & $0 / 2$ & 0 \\
\hline & & $\mathrm{R}$ & $?$ & \multirow{2}{*}{$21 \mathrm{EV}$} & \multirow{2}{*}{$>6 \mathrm{~h}$} & \multirow{2}{*}{16} & \multirow{2}{*}{$0 / 16$} & \multirow{2}{*}{0} \\
\hline & & $\mathrm{L}$ & $?$ & & & & & \\
\hline \multirow{2}{*}{$\begin{array}{l}\text { Brandt et } \\
\text { al.[5] }\end{array}$} & \multirow{2}{*}{25} & \multirow{2}{*}{$?$} & $1 \mathrm{IV}$ & & \multirow{2}{*}{\multicolumn{2}{|c|}{$>6 \mathrm{~h}$}} & \multirow{2}{*}{$0 / 25$} & \multirow{2}{*}{0} \\
\hline & & & $24 \mathrm{EV}$ & & & & & \\
\hline \multirow{3}{*}{$\begin{array}{l}\text { Djahangirian } \\
\text { et al. [9] }\end{array}$} & \multirow{3}{*}{48} & B & 2 & & & & & \\
\hline & & $\mathrm{R}$ & 22 & $?$ & & & $5 / 48$ & $10 \%$ \\
\hline & & $\mathrm{L}$ & 20 & & & & & \\
\hline & & B & 2 & $1 \mathrm{IV}$ & & & & \\
\hline $\begin{array}{l}\text { John et al. } \\
\text { [10] }\end{array}$ & 26 & $\mathrm{R}$ & 13 & $25 \mathrm{FV}$ & & & $0 / 26$ & 0 \\
\hline & & $\mathrm{L}$ & 9 & $25 \mathrm{LV}$ & & & & \\
\hline & & B & 1 & & $<6 \mathrm{~h}$ & 1 & $1 / 1$ & $100 \%$ \\
\hline $\begin{array}{l}\text { Arena et al. } \\
\text { [11] }\end{array}$ & 8 & $\mathrm{R}$ & 2 & $8 \mathrm{EV}$ & $-6 \mathrm{~b}$ & 7 & 0 & 0 \\
\hline & & $\mathrm{L}$ & 4 & & 801 & 7 & $0 / 7$ & 0 \\
\hline & & B & 3 & & $<6 h$ & 8 & $2 / 8$ & $25 \%$ \\
\hline $\begin{array}{l}\text { Pinto et al. } \\
\quad[12]\end{array}$ & 11 & $\mathrm{R}$ & 3 & $?$ & $76 \mathrm{~b}$ & 2 & $0 / 2$ & 0 \\
\hline & & $\mathrm{L}$ & 2 & & $>011$ & 3 & $0 / 3$ & 0 \\
\hline & & B & 2 & & & & & \\
\hline $\begin{array}{l}\text { Kaye et al. } \\
\text { [13] }\end{array}$ & 15 & $\mathrm{R}$ & 7 & $?$ & $>6 \mathrm{~h}$ & & $0 / 16$ & 0 \\
\hline & & $\mathrm{L}$ & 4 & & & & & \\
\hline
\end{tabular}

\section{Conclusion}

When risk of anesthesia in the newborn and the low salvage rate of PTT is considered, conservative approach should be chosen and elective surgery should be done instead of emergency surgery.

\section{Conflicts of Interest}

There is not a conflict of interest between the authors.

\section{References}

1. Al-Salem AH (1999) Intra-uterine testicular torsion: early diagnosis and treatment. BJU Int 83(9): 1023-1025.

2. Burge DM (1987) Neonatal testicular torsion and infarction aetiology and management. Br J Urol 59(1): 70-73.

3. Vander Sluijs JW, den Hollander JC, Lequin MH (2004) Prenatal testicular torsion: diagnosis and natural course. An ultrasonographic study. Eur Radiol 14(2): 250-252. 
4. Yerkes EB, Robertson FM, Gitlin J, Kaefer M, Cain MP, et al. (2005) Management of perinatal torsion today, tomorrow or never. J Urol 174(4 pt 2): 1579-1582 discussion 1582-1583.

5. Brandt MT, Sheldon CA, Wacksman J, Matthews P (1992) Prenatal testicular torsion: principles of management. J. Urol 147(3): 670-672.

6. Sorensen MD, Galansky SH, Striegl AM, Mevorach R, Koyle MA. (2003) Perinatal extravaginal torsion of the testis in the first month of life is a salvageable event. Urology 62(1): 132-134.

7. Driver CP, Losty PD (1998) Neonatal testicular torsion. Br. J. Urol. 82: 855-858.

8. Samnakay N, Tudehope D, Walker R (2006) Spin on perinatal testicular torsion. J Paediatr Child Health 42(11): 734-736.

9. Djahangirian 0, Ouimet A, Saint-Vil D. (2010) Timing and surgical management of neonatal testicular torsions. J Pediatr Surg. 45(5): 1012-1015. doi: 10.1016/j.jpedsurg.2010.02.032.

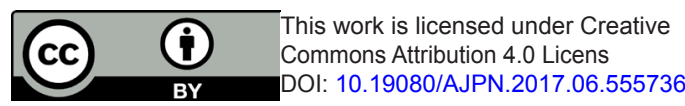

10. John CM, Kooner G, Mathew DE, Ahmed S, Kenny SE. (2008) Neonatal testicular torsion--a lost cause? Acta Paediatr. 97(4): 502-504. doi: 10.1111/j.1651-2227.2008.00701.x. Epub 2008 Mar 7.

11. Arena F, Nicotina PA, Romeo C (2006) Prenatal testicular torsion: Ultrasonographic features, management and histopathological findings. Int J Urol 13(2): 135-141.

12. Pinto KJ, Noe HN, Jerkins GR (1997) Management of neonatal testicular torsion.J Urol. 158(3 Pt 2):1196-7.

13. Kaye JD, Levitt SB, Friedman SC, Franco I, Gitlin J, et al. (2008) Neonatal torsion:a 14year experience and proposed algorithm for management. J Urol. 179(6): 2377-2383.

14. Olguner M, Akgur FM, Aktug M (2000) Bilateral asynchronous perinatal testicular torsion: a case report. J Pediatr Surg 35(9): 1348-1349.

\section{Your next submission with Juniper Publishers will reach you the below assets}

- Quality Editorial service

- Swift Peer Review

- Reprints availability

- E-prints Service

- Manuscript Podcast for convenient understanding

- Global attainment for your research

- Manuscript accessibility in different formats

( Pdf, E-pub, Full Text, Audio)

- Unceasing customer service

Track the below URL for one-step submission https://juniperpublishers.com/online-submission.php 